\title{
Respectful Resistance: Young Musicians and the Unfinished Revolution in Tunisia
}

\author{
Sofia Laine, Leena Suurpää and Afifa Ltifi
}

I am an unknown creature yelling high behind my microphone singing all alone, provoking silence in quiet places 'Heartless places'

WAEL MESKINI $2011^{1}$

The Tunisian Revolution in January 2011 initiated a wave of Arab-Mediterranean uprisings, all articulating their demands with democracy, social justice and dignity (Glasius and Pleyers 2013). In the post-revolutionary Arab world, multiple art forms have been used to fight for the recognition of the diversity of political expressions by young people, as Wael Meskini's lyrics above indicate. The aim of this chapter is to analyse the meanings of music in relation to young people's civic engagement in Tunisia by listening to the life stories of young Tunisian musicians.

In earlier studies it has been claimed that the overall discontent and lack of trust in public institutions on the part of the young in post-revolutionary Tunisia have been made visible through cultural channels, especially through diverse genres of music (Mannone 2012; Skalli 2012). We continue this discussion by exploring multiple meanings ascribed to the notion of resistance among young musicians in Tunisia. The conceptual pair of youth and resistance is often treated in connection with state-centred arenas, manifest political participation as well as overt dissent on the streets. This leads easily to somewhat spectacular accounts of young people's resistance, leaving aside its diverse everyday modes, agencies and spaces (see Bayat 2013). By examining the informants' reflections on the roles of music in their lives, and by listening to their music and lyrics, we aim to analyse the complexities of youthful civic action through music in Tunisia with the concept 'respectful resistance'.

Resistance is often seen as a reaction to individual or collective oppression, whether overt or invisible. In its traditional usage, resistance is embedded in the

1 Translated from Arabic to English by Afifa Ltifi.

(C) SOFIA LAINE ET AL., 2018 | DOI 10.1163/9789004356368_005

This is an open access chapter distributed under the terms of the CC-BY-NC License, 
exercise of oppression by a ruling group (see Young 2000). This understanding of resistance also seems reasonable in the Tunisian post-revolutionary context. In this article we highlight the contested understandings and manifestations of resistance among young Tunisian musicians. We discuss how the notion is jointly embedded in respect for the country's cultural heritage and its musical tradition, and the struggle for material, cultural and social change.

The concept of 'respectful resistance', attached here to post-revolutionary conditions in Tunisia, has been used in various fields and contexts and refers to the multiple tensions embedded in the acts of negotiating with and challenging different authorities (parents, teachers, politicians) while acting as musician (see also Quiñones 2015). These young musicians, after growing up during President Ben Ali's authoritarian regime, are obliged to express their discontent in creative ways in spaces in which artistic expression may be limited, challenged or even dangerous. After our field work in Tunisia, the state of emergency law that was put in place in November 2015 after several terrorist attacks was extended several times. The law allows, for example, the banning of strikes and meetings, the temporary closure of theatres and bars and measures to control media. Street art and the use of public space for different types and forms of non-violent argumentation, providing a diversity of counter publics in the public sphere (Palma 2014), have an especially important function in embodying and representing freedom of expression and maintaining recently gained citizenship rights.

In the next section we provide a brief background to the role of music in Tunisia, to our research process and to our informants. Then we discuss the concept of respectful resistance in our informants' artistic exercise at two intersecting levels: first, on the continuum of respect for tradition and the quest for change; second, in terms of generational dialogue and conflict. We conclude the chapter by underlining the importance of in-depth analysis of artistic modes of 'respectful resistance' by young people, especially in societal situations in which citizenship rights and freedoms are actively contested. This article is also written with respect at a delicate moment in Tunisia's history, in order to understand better how these young 'engaged artists' strive on a daily basis for deeper democracy and a more open society through their lyrics and performed songs.

\section{Music in Tunisia: Academic Discussion and Fieldwork}

During and since 2011, hip hop scenes with their revolutionary dimension have gained much attention both in the academy and media. It marked a unique moment where rap lyrics were considered relevant and were heard attentively 
by different age groups. Academic scholars have contributed to a similar kind of embrace of the new roles and visibilities of rap artists in cultural production. Nouri Gana $(2012,26)$ observes that "rap music has contributed to the dissemination of a culture of dissent, wakeful to societal and economic problems and mindful of popular preoccupations and concerns", thus describing hip hop culture as "an unlikely democratizing force, implying its largely amateurish nature and its committed political agenda". According to Brigit Englert $(2008,8)$, the perception of music as an empowering counter-hegemonic force has shaped the perspective of many scholars, to the extent that its 'resistant' character is sometimes taken as a defining characteristic.

The existing research literature gives no uniform account of the significance of music in Tunisia in different historical periods. On the one hand, the musical history of the country has been characterized as particularly mixed, blending different cultural and linguistic inspirations - Berber, Turkish, Andalusian, African, European, particularly French and increasingly North American, albeit often via France, to mention a few. This has been claimed to provide an enriching platform for a lively tradition of popular music, discussed with terms such as polyglossia, inter-musicality and hybridity. (Mannone 2012; Hakima 2011; Korpe 2013.) It seems that the very meaning of Tunisian popular music in conceptual terms is rather ambivalent, regardless of whether we look at its 'mainstream', 'folk', 'alternative' or 'underground' dimensions. ${ }^{2}$ However, scholars rather unanimously state that the political dimension of the music in Tunisia has multiple sources, roots and pieces of tradition that pre-date the revolutionary processes of recent years. Since Tunisia became independent in 1956 each regime has favoured a particular music genre: Tunisia's first president, Habib Bourguiba (1957-1987), elevated Andalusian and Turkish-inspired malouf to the status of 'national' music, and Ben Ali (1987-2011) associated the mezwed with working-class origins (Kraft 2012).

In addition to favouring particular music genres, cultural censorship and a fear of artists on the part of the political elite were a central part of the history of popular music in Tunisia more or less throughout the regimes of Bourguiba and Ben Ali. Benoit Challand $\left(2013,5^{-6}\right)$ calls the period from 1930 to 2010 the "age of ideologies" in the Middle East, characterized by forced homogenization of national identities. The solidification of state control and of a unified version of identity building also had its impact on the music culture in Tunisia. As Mannone $(2012,61)$ describes: "The various fields of Tunisian cultural

2 Popular music literally translates in the Tunisian context to Chaabi music which is associated with folkloric Mezwed music. Hip Hop can be also considered as Chaabi as it is accessible to people with different backgrounds, and it is claimed to speak to the marginalized. 
production were therefore structured to favour those artists whose works were politically neutral or focused on social issues that would have favoured the regime's policies." The homogenizing effects of the regimes of Bourguiba and Ben Ali are claimed to have contributed to the lack of knowledge of the plurality of the music traditions in Tunisia. Now, in the post-revolutionary period, this diversity of cultural roots has been celebrated, mixed and fused.

If academic scholars provide competing arguments on how music matters in terms of public debate and societal change, so do the musician informants in this study. Eight amateur musicians were interviewed for this article, three of them collectively as they came from the same music group. The interviews were conducted by Afifa Ltifi, a young Tunisian scholar and civic activist residing in Tunis, who directly contacted some of the informants herself (some of whom she knew beforehand); these informants then recommended other musicians. Ltifi also translated the lyrics of those songs that have been used in this article, being originally in Arabic language.

The music scenes of Tunisian youth do not necessarily stem from the most marginalized parts of society - socioeconomically, culturally or racially. Owning a musical instrument is most common among young people whose families are financially comfortable and/or socially aware of the importance of a hobby, be it music or sports, for their children. The interviewed musicians (aged 20-31.) also mostly come from middle-class and relatively welleducated backgrounds. While only one of the informants is a woman, themes related to the gender divide in Tunisian music scenes were discussed in every interview. It should also be mentioned that only one informant belonged to a black minority group, yet issues related to race, music empowerment and liberation reverberated in the accounts of some artists. At the time of the interviews, spring and summer 2013, many of the informants were university students. Four of them come from the north and three others from the south, yet all lived in Tunis at the time of the interviews, which coincided with the first parliamentary elections since the revolution had taken place two and half years earlier. The biggest and ruling party was Ennahda, a moderate Islamist political party whose victory was a disappointment for many secularist youth. Thus, research was conducted at a period when Ennahda was in power.

The team work among the three authors of this article, from sketching the research design to the reporting phase, demanded a readiness to share both personal and scientific reflections related to the research topic with the co-researchers (Laine et al. 2015; Jabberi and Laine 2015). Furthermore, our collective work entailed critical conversations not only related to the research topic, field work and empirical material per se, but also to the overall Tunisian 
context in which the research issue was embedded. When researchers have different knowledge, positioning and emotional attachment with regards the topic, team work challenges them to 'go beyond what I know'. After careful reading of the transcribed data, a week consisting of collective discussion and analysis was set up in Helsinki in June 2014. During the week, the concept of 'respectful resistance' crystallized as a tentative conclusion to our discussion, and a conceptual framework for this article.

\section{"Revolution is a life style"}

\section{Live Art}

Live art and don't feel weary

Just jump brother, don't step back

Live art and don't shut your mouth

Live at wherever you want

Live art in every city

you have it all in your hands

Draw on our neighbourhoods' walls with your colours

You artist, you are everything

Live art with all its colours

With all its lyrics and rhythms

The citizen is the artist of his age

Live your art without borders

Live your art in alleys, deserts and neighbourhoods

NOUVEAU SYSTEME $2011^{3}$

How do the interviewed musicians articulate the issues related to change and respect for tradition? The excerpt of the song and the statement, "Revolution is a life style", manifests the ethos that is largely shared among the interviewed musicians, one which resists any simple oppositional stance toward the hegemonic culture, political elite or the parents' generation. During the Ennahda regime (2012-2014) urban, secular, educated young people felt disillusioned and sidelined from the political process, and the aim to continue the revolution is also visible in the lyrics and narratives of the interviewed young musicians. They call for breaking the culture of silence and the imposed authoritarian discourse of Tunisian cultural and political life. The lyrics of the song cited above celebrate the heterogeneity and freedom of artists and

3 Translated from Tunisian Arabic to English by Afifa Ltifi. 
encourage everyone to practice art - whatever the art they espouse. It is a call to expand the cultural sphere in Tunisia and to struggle to widen the space for the civic engagement of Tunisian citizens.

The interplay between music, civic action and social change is far from simple. As one of our informant puts it:

It is true that almost everyone wants to talk about the revolution. It is becoming a trendy commercial thing, but we are not working from that standpoint. We are singing for the revolution and not about the revolution. We are singing for the continuity of the revolution. Our goal is not to sing, our goal is to historicize what is happening now with art. You will see how history will be written 10 years from now. History won't be written the same way we lived it on the 14th of January, it will be written according to the understanding of the fittest 10 years from now. My goal as a Tunisian is to make a song so history will not be falsified one day; this is the least one can do. Another goal is to keep reminding people that there is hope ... A revolution is not a day or two, a year or two; a revolution is a life style, a revolutionary life. If you want to make progress in life you have to lead a revolutionary life ... We are apolitical, and any politician or anyone who goes astray one day we will attack him in our songs and anyone who does something good we will recognize his success as well.

The account of this 22-year-old male informant reveals how the young musicians see themselves as civic actors in the middle of an unaccomplished reformatory process, thus contesting other commentators on the contemporary condition of Tunisia. For this informant, the task of musicians is to historicize a significant and ongoing period in Tunisia. A similar line of argument can be found in the interviewed female musician's story: “I didn't write about the Tunisian revolution, and I can't write about it because I feel that I'm still under its spell; we are still in a revolution. I feel I can't be creative in something that hasn't finished yet."

The interviews highlight the reformatory rather than rebellious understanding of resistance. The description by the famous Tunisian rapper, El Genèral - "The goal is not revolt but reform" - is equally shared among the interviewed musicians. Music's potential as a tool for social change is understood as the capacity to speak for multiple audiences and to enlarge public spaces in which people from different backgrounds may articulate their visions of society and its future. Rather than being a soundtrack for the revolution (Westin 2013), which has become a common label for the musical 
scenes throughout North Africa, the interviewed musicians tell a story about a soundtrack for the democratic citizenship of Tunisians that aims to talk to the people, to evoke the people, to unify the people. The lyrics in the Live Art song from Nouveau Systeme quoted above tell the story of the sombre societal situation in 2011: "Today life is like a jungle, everyone aspires to power, dreams of killing, and burning lives." The lyrics position musicians as a counterforce to this development, struggling for the good life, as the song of one of our informants makes manifest: "We are not asking for money or fame, we want our life today to get brighter."

It is easy to find resonance with what Paolo Freire describes (1970, 21-22), as "conscientization" (i.e. the deepening process of awaking consciousness) in his framework of cultural action for freedom: "Little by little, as these possibilities multiply, the learners, through mastery of new generative words, expand both their vocabulary and their capacity for expression by the development of their creative imagination." In this framework, the freedom of expression is tightly connected to the freedom of civic thought, and to building critical understanding and knowledge of what is going on in Tunisia. In this light the quotation from our male informant above, and his expression of his life politics, gets a particular meaning. It is the story of a civic actor. At the same time, it stands in contrast to the stereotype of the (African) artist characterized as a primarily political actor whose ability is valued to the extent to which he/she is able to involve him/herself in overt (dis)approval of politics. The idea of conscientization is encoded in the narratives and lyrics, which contribute to capturing the identities and histories of the Tunisian people. This kind of process, wherein the particular societal moment is 'composed' musically, has been the topic of many studies examining the political and emotional power of music (Street 2012, 98-117).

A relevant question is the degree to which this kind of conscientization, and the resistance embedded in it, can be considered voluntarily chosen, and how much it is a result of the limited opportunities for young musicians to attain a legitimized position in the political and cultural spheres, thereby leading to the search for compromises and 'revolutionary diplomacies'. In the interviews, young cultural actors in Tunisia are also positioned as an oppressed group in the face of the cultural imperialism of Tunisian society (Young 1990, 6o), regardless of their important roles in the course of the revolution.

The song Live Art, cited above, and the informants' stories, encourage us to argue that the creative production of music needs to be reconceived as a civic process rather than a heroic act (see also Toynbee 2012, 168). Both the lyrics and the interviewees' accounts contest any simplistically assumed revolutionary character to the music of the young generation. Rather, they 
come close to those scholarly arguments which approach politics as an intrinsic, although often hidden, unit in any artistic production, as argued, for example, by Howard Becker (1974) in his classical discussion of art as collective action. One example of this is the use of language in the music. A number of the interviewees strive towards mixing different languages in order to reform the heritage of Tunisian music, to reach a transnational audience, but also to use the Tunisian dialect as a powerful means to reach the Tunisian people with stories about the societal problems of the country. For instance, the female interviewee included standard Arabic in the language used in her lyrics, something relatively rare in contemporary Tunisia. Young people of her age readily consider standard Arabic in music or poetry archaic and dull, sometimes even funny.

The interviews also highlight the importance of what can be called everyday art politics: a willingness on the part of the young musicians to raise daily topics of ordinary Tunisian life that are rarely discussed in public life or that have been consciously muted. The lyrics of the informants' music groups concern a set of silenced stories from Ben Ali's regime before the revolution: poverty, unemployment, institutionalized violence and corruption, cultural censorship, the precarious future vision of the youth and their political mistrust. By referring to experiences of the interviewed Tunisian activist groups, the researcher Tilia Korpe (2013) states in her study, Artivism in Tunis, that it has become easier for young people to express views on issues related to human rights and freedom of expression.

However, music's power to evoke hidden histories seems to have its restrictions (see also Street 2012). It is still hard to expose socio-economic problems, as it has been in the past, despite the high rate of unemployment and other economic problems in contemporary youth-dense Tunisia. The crucial struggle that seems to unify the interviewed musicians is how to bring together the politics of dignity - referring to civic entitlement and human rights - and the politics of justice - referring to poverty reduction, fair employment and governmental schemes, and how music could contribute to this struggle. Following Nancy Fraser's classical framework (2008), the issue is whether cultural recognition can be extended so as to enhance redistribution in material terms (see also Appadurai 2008).

While highlighting the everyday miseries of Tunisian people, the lyrics can also be interpreted as narratives of hope, love and respect for the country's rich heritage. A similar double message has been found by Nouri Gana (2012, 42) in his analysis of Tunisian rap. Sombre stories of securitization, corruption and injustice go hand in hand with the search for the politics of fun, implying diverse carnivalesque tones in the cultural sphere. 


\title{
Dynamics within and between Generations
}

\author{
She is a W.O.M.A.N \\ She is an emotional woman \\ She is a woman who isn't ashamed when she leaves her lover's house \\ She is a woman who loves butterflies \\ She is a woman who dreams of a rebellious poet \\ She is a woman lost in an ignorant world \\ BIANCA LA GITANA $2008^{4}$
}

The lyrics cited above are written by one of the few female slammers in Tunisia, adopting the subgenre of improvised and rhythmic storytelling, a sort of musical poetry. Her lyrics are polyphonic stories about emotions, embodiment, dreams, loss and misunderstanding - themes that young women in Tunisia tackle daily. For the female informant, her main concern has to do with young women's artistic aspirations and opportunities and the injustice that they experience in masculine fields of music. Both her interview and the male informants' narratives tell of multiple forms of marginalization that young females face while making music in Tunisia today. One of our male informants, however, justifies why it is difficult for him to work with females:

Unfortunately when you have a female with you, you can't do anything. When we have a concert late at night, her family do not allow her [to perform]; when we want to have rehearsals we need to wait for holidays for her to be available. So females create many obstacles that hinder your progress and women get tired of all that and lose interest with the excess of hardships. It is so rare to find rebellious women who start standing up to their families and manage to make it.

Another male informant from the same music group continues:

You can mostly find women in Rock and Metal. Yet women are always unavailable for that; our culture and our society still perceive a woman as unable; and she should not be seen hanging out a lot or working with men. In our group work we consult women and there are a lot of female figures who help us and give us advice whenever necessary.

4 Translated from French to English by Leena Suurpää. 
While the interviewed young male musicians sing about equality and justice for all, they hardly see young female musicians as fully legitimate actors in their music scene. Rather, they are depicted as assistants or consumers of music whose everyday lives and leisure activities are in many ways shaped by patriarchal norms, and justification for this is based on societal conditions rather than personal attitudes toward female musicians. Our female informant's interview entails a set of critical commentaries on this issue:

I write for women and about women. I talk about social schizophrenia and hypocrisy, or the way the society looks at women, as I have a text that talks about women who get divorced and about virginity problems and also about love.

When talking about social schizophrenia and hypocrisy she does not only address her criticism to the government and the patriarchal structure of the country. Her story can be equally read as a counter-narrative to the common discourse of female passivity in public life, among both old and young, including the stereotype of the marginal position of young women in music scenes. In these kinds of accounts, paternalist attitudes towards women's respectability with regard to public performances, family duties and sexuality seem to be intertwined with indifference about women's artistic struggles or even explicit discrimination against female colleagues. According to the musicologist Alyson E. Jones (2010), who has done significant ethnographic work among Tunisian female musicians, the latter have gradually expanded definitions of respectability while remaining respectable. The concept of respectful resistance seems pertinent also in this context: the female artists have gradually reformed the field of music by successfully gaining roles which may be perceived as both respectable and disruptive. Especially in terms of Street Poetry women have not only reclaimed space from the state, but from men as well (Palma 2014, 11).

The narrative of the female informant can be read as a personal struggle to imagine alternative realities with the help of art. She explains that her mother "used to tell me that studying should be a priority and art should remain a hobby". Nonetheless, she remained active in writing, and had already participated in a poetry and short novel contest by the age 10. In addition she was engaged by a radio channel during Ben Ali's regime: "I started reading my poems which were in the form of letters: letters for my dead grandfather, my mother, father, and the daughter that I don't have yet." After these performances, she was introduced to slam: "Afterwards we had the Street Poetry project, and the first session of this project that took place during Ramadan. I was the only girl performing slam that night." 
It seems that the forms of injustice that the young musicians face in Tunisia are not only gendered but also have to do with generational disputes. In this context, the interviewees addressed their criticism to the shortage of trustworthy social networks - among the young, between young and old, and between professional and amateur artists. As our female informant describes: "The biggest hardship was when some people wanted to shut my mouth out of jealousy. I hate saying that honestly. There are people who will erase your name from the list of participants." Intra-generational contests among young musicians get critical attention in the interviews. Our female informant regrets that the shortage of economic and cultural resources to make the music public may easily contribute to conflicts rather than solidarity between young artists. This, in turn, further weakens the socio-cultural position of these actors in society.

One dispute has to do with interpretations of the political dimension of the music produced by young people, particularly in the course of the revolution. The interviewees claim that the process of the politicization and commercialization of the music may go hand in hand. One of the male informants, a partisan of civic engagement, somewhat paradoxically regrets the ongoing trend in the Tunisian music scene of the young generation, saying, "Almost everyone wants to talk about the revolution. It is becoming a trendy commercial thing, but we are not working from that standpoint." The same kind of ambivalence is also echoed in other interviews. Rap music, which has gained a salient position in the political engagement of the musicians in Tunisia, is not exempt from such critique. One of the informants formulates his criticism in the following way:

But rap is not music to be performed by anyone. You should study it and get a deeper insight into it to be able to understand. Many are becoming rappers randomly without thinking. Some have a divine gift and can do it and just need to hone that skill. In Tunisia, those who have potential and skills are not able to hone them and those who have no skills are able to be popular and become famous.

The field of so-called underground music also gives rise to hesitant attitudes:

I think it is artificial. We have a tendency to copy-paste in Tunisia. We have amateurs who do not initiate their own music; they keep copying and making cover songs ... Also it should not remain underground; an artist should fight for his art and make his music well known for those who love it and for those who don't. 
Ultimately, there seems to be a set of disagreements on how to revise the concept of 'committed art' in the current musical scene in Tunisia (see also Gana 2012, 26). Here we come back to the classic debate over the "urge to 'authenticity", and its counterpoint, "the fear of being 'inauthentic", as Simon Frith $(1988,22)$ phrased it in his analysis of the political affiliations of music, starting from jazz in 1950 s Britain. The rap culture seems to represent a particular symbolic target in contemporary Tunisia in this respect: claims about an overdose of political rap merge with claims of the neglect of other young musicians and their music genres. The ambiguity does not only concern rap music as such. It is a part of the dispute regarding the meaning of 'politics' in music, ranging from aspirations to enlarge the understanding of what the political responsibility of the artist may entail, to aversion towards politics as whole, independently of whether it refers to the government regime or the commercial politicization of music scenes. This is manifested in an illuminating way in the account of the informant whose group's aim is to blend different musical styles, to rethink current musical trends in Tunisia:

We can be engaged with certain values that aren't necessarily political. We selected the alternative genre because the political one will limit our potential. Militant music will restrict us to a certain audience while we want to expand our audience and please all tastes regardless of people's differences and belonging, ideologies. Our music is for all Tunisians. We are aiming to be a new fresh breath that will lift people from the current situation and stressful mood that has started to overwhelm the political and social life in the country. We tend to sing for people in open spaces to be closer to them; we hate being restricted in a genre or a place ...

Furthermore, the interviews reveal an interesting ambiguity about intergenerational dialogue regarding the production of music. On the one hand, their music is seen as a means to (re)-establish dialogue between young and old, as one male informant describes: "Of course people do not accept new things easily and it is normal to face rejection. But we didn't allow that to happen with us as we tried to please all ages. Our songs can be audible for older and younger generations." The interviews are also stories about young adults, mostly from relatively prosperous backgrounds, whose artistic biography has been affected by the support of their parents. On the other hand, independence from their parents' generation, including in musical terms, is seen as a way to tackle the powerlessness of young people in the face of the older decision-makers of Tunisian society. In the same way, proceeding in an artistic career is seen as a way to gain more freedom to rethink cultural traditions in a respectful but reformative manner. 
The loyalty expressed towards their parents' generation can be seen as a subthe form of auto-censorship. The young artists feel pressured to reassure their parents and other older relatives about the mindfulness of the music and lyrics they produce. This sort of auto-censorship resonates with the generational power relations. Tunisian youth constantly grapple with archaic perceptions of inter-generational relations that have survived the revolutionary processes. What is more, art has always been frowned upon in local culture - networks of religions, families and relatives. So, alongside expressions of gratitude for certain aspects of the heritage of earlier generations, there are narratives exposing a set of inter-generational disagreements and ruptures. One source of disagreement concerns the possible future artistic careers of young people. The interviews reveal that parents do not want that of their children to lie in the artistic field even if they like the music their children are performing. This reluctance seems to be very much linked with their fears concerning the socioeconomic uncertainty of the artistic career, whether amateur or professional.

\section{Respecting Respectful Resistance}

This chapter has examined the roles and meanings of music in the civic engagement of young musicians in contemporary Tunisia. The young musicians enjoyed increased artistic freedom during and right after the Tunisian Revolution in 2011 for a couple of years, and used it to build polyphonic public space with diverse claims, visions and aspirations for civic engagement. The post-revolutionary music scene expanded considerably, especially through social media. However, after several terrorist attacks in 2015 and predicating with the state of emergency law, the authorities have also become more intolerant towards artistic expression, and the future of cultural space in Tunisia is highly unclear.

We have applied the concept of respectful resistance as an analytic framework to discuss how young musicians strive for social change while not insisting on overt confrontation with society and its prevailing social order. The concept emphasizes that recognition of Tunisian cultural heritage and its musical tradition and the struggle for cultural and social change may be articulated as joint aspirations for the young musicians. The understanding of respectful resistance that concurrently encourages reconciliation and struggle does not imply that the musical scenes of the informants should be characterized as conservative, timid or mainstream.

The concept highlights the importance of a broad framework when analysing intergenerational encounters in the creation and development of 
musical scenes in Tunisia, both at the level of personal biographies and in more institutional terms. As Henri Onodera (2015) shows in the context of Egypt, increased forms of youth activism in the 2000 s have promoted a critical generational consciousness and provided new meanings to the notion of youth as a rebellious political category, and in some ways a privileged experiential realm, ready to conduct collective resistance on its own terms. Ultimately, it seems evident that there is a great need to adopt a contextually sensitive approach to the issue of resistance and what constitutes its transformative potential when studying the role of music in youth engagement in Tunisia, Africa or elsewhere (see also Bayat 2013; Chomiak 2011; Mannone 2012; Englert 2008).

The narratives of the young musicians reveal the scarcity of socio-economic resources to pursue their artistic interests, a challenge that concerns both Tunisia and the larger African context (Englert 2008). What is more, dominant cultural trends in Tunisia seem to arise mostly from the masculine and urban population, leaving feminine, rural and different ethnic communities relatively marginalized in the articulation of new subjectivities, messages and artefacts in the field of musical production, regardless of the strong claims to cultural hybridity and equality of the young musicians. This is true in spite of the fact that young Tunisian women are well educated (although often unemployed) in comparison with other countries in North Africa and the Middle East, and it is often explicitly stated that they enjoy a culture of equality unmeasured elsewhere in the region (Ennaji and Sadiqi 2011).

The 'political' dimension of the music produced by young Tunisians is highly disputed in the interviews. For the interviewed musicians, music seems to symbolize both an escape from the state-dominated arena of formal politics and an intrinsic part of their everyday politicization. The transformative potential of music is connected both to the material and cultural conditions of the artistic activities of the interviewed young musicians at the daily level, and with their conscientization efforts in society through the medium of their music. It is also seen as a powerful means to gain visibility and fame, if not a livelihood, thus having links to the commercialization of musical scenes in Tunisia. This is by no means a Tunisian phenomenon, nor a recent issue. The scholars analysing the interplay between music and politics state that the commodification of music - with its cultural 'banalization', music industries and so on - cannot be seen solely as a matter of regret. It should also be analysed as a significant element of social change. (See i.e. Attali 1985; Street 2012.).

The concept of respectful resistance encourages us to look beyond explicitly political songs or forms of performance. The British writer Dave Laing (2003, 345) has made a distinction between "protest music" and "music of resistance", pointing out the importance of the context wherein the music is produced, 
performed and consumed. He describes protest music as comprising explicit statements of opposition concerning a specific issue or enemy; music of resistance, on the other hand, is seen as more coded or opaque in its nature, without an explicit narrative of 'us' and 'them'. Its politics may lie in the mere act of singing. (See also Street 2012.) In the context of the interviewed Tunisian musicians, the understanding of music as resistance is pertinent, even if elements of protest music may be found in their lyrics and interviews.

In this context, the notion of respect acquires multiple meanings when connected to the narratives of the interviewed Tunisian musicians, referring to the contested interpretations of, and conditions for, recognition and entitlement in personal, cultural and material terms. It may be seen as a metaphor for the democratic pluralism and revolutionary process for which the interviewees are fighting with their music. The struggles of the interviewed musicians concern their relations with young fellow musicians and parents at the everyday level, as much as the political elite and state control at a more systemic level.

Finally, respectful resistance can be considered a result of both the oppressed position of young musicians in Tunisia, and of their tactical choice to search for alternative spaces, forms and channels of engagement in order to reach out to wider publics. In post-Ben Ali Tunisia, it has implied a careful blend of local and transnational influences into cultural production in terms of rhythm and genres, instruments, performances, language and the discourses used in the lyrics. As such, it can be conceived as the mode by which young Tunisian musicians claim to be taken seriously and also as a way to command respect, power and authority from others.

\section{References}

Appadurai, Arjun. 2008. "The Capacity to Aspire: Culture and the Terms of Recognition." In Cultural Politics in a Global Age. Uncertainty, Solidarity and Innovation, ed. David Held and Henrietta L. Moore, 29-35. Oxford: Oneworld Publications.

Attali, Jacques. 1985. Bruits. Essai sur l'économiepolitique de la musique. Fayard: Presses Universitaires de France.

Bayat, Asef. 2013. Life as Politics. How Ordinary People Change the Middle East, 2nd edition. Stanford: Stanford University Press.

Becker, Howard. 1974. "Art as Collective Action." American Sociological Review 39 (6): 767-776.

Bianca la Gitana. 2008. Elle est une F.E.M.M.E... (She is a W.O.M.A.N.) Not recorded. Challand, Benoît. 2013. "Citizenship against the Grain: Locating the Spirit of the Arab Uprisings in Times of Counterrevolution." Constellations 20 (2): 1-19. 
Chomiak, Laryssa. 2011. "The Making of Revolution in Tunisia." Middles East Law and Governance 3: 68-83.

Englert, Birgit. 2008. "Popular Music and Politics in Africa - Some Introductory Reflections." Special Issue on African Music in Wiener Zeitschrift für Kritische Afrikastudien 14: $1-15$.

Ennaji, Moha, and Sadiqi, Fatima. 2011. Gender and Violence in the Middle East. London: Routledge.

Fraser, Nancy. 2008. Scales of Justice: Remaining Political Space in a Globalizing World. Cambridge: Polity.

Freire, Paulo. 1970. Cultural Action for Freedom. Massachusetts: Harvard Educational Review, Monograph series no. 1.

Frith, Simon. 1988. Music for Pleasure: Essays in the Sociology of Pop. Cambridge: Polity Press.

Gana, Nouri. 2012. "Rap and Revolt in the Arab World." Social Text 113/ Winter 2012: $25-53$.

Glasius, Marlies, and Pleyers, Goeffrey. 2013. The global movement of 2011: Democracy, social justice and dignity. Development and Change, 44 (3): 547-567.

Hakima, Fakher. 2011. "Examples of Tunisian Intermusicality: Particularism and Universalism.” In Music and Solidarity. Questions of Universality, Consciousness and Connection, edited by Felicity Laurence and Olivier Urbain, 61-72. New Jersey: Transaction Publishers.

Jabberi, Fatma, and Laine, Sofia. 2015. "Spaces of dialogue? The case of the World Social Forum Tunis 2013 from the perspective of young, local volunteers." Global Studies of Childhood 5 (2): 178-190.

Jones, Alyson E. 2010. “Playing out: Women Instrumentalists and Women's Ensembles in Contemporary Tunisia." A dissertation submitted in partial fulfillment of the requirements for the $\mathrm{PhD}$ degree in musicology, University of Michigan, Ann Arbor. http://deepblue.lib.umich.edu/bitstream/handle/2027.42/78752/aejones_1.pdf (accessed 9.1.2017).

Korpe, Tilia. 2013. "Artivism in Tunis. Music and Art as Tools of Creative Resistance \& The Cultural Re: mixing of a Revolution.” Master's thesis, Malmö Högskola, Malmö. http://muep.mah.se/bitstream/handle/2043/15526/Tunisian\%2oArtivism\%2o by\%2oTiia\%2oKorpe.pdf?sequence $=2$ (accessed 9.1.2017).

Kraft, Jessica C. 2012. After the revolution, arts bloom in Tunisia. The Christian Science Monitor. http://www.csmonitor.com/The-Culture/Music/2012/0209/After -the-revolution-arts-bloom-in-Tunisia (accessed 13.10.2016).

Laine, Sofia, Elina Oinas, Leena Suurpää, Tiina-Maria Levamo, Henri Onodera, Piia Lavila, and Minna Rantama. 2015. "Polyphonic Ethos in Team Research: Lessons from the World Social Forum Tunis 2013". In In Search of ...” New Methodological Approaches to Youth Research, edited by Airi-Alina Allaste and Katrin Tiidenberg, 116-135. Cambridge: Cambridge Scholars Publishing. 
Laing, Dave. 2003. "Resistance and Protest". In Continuum Encyclopedia of PopularMusic of the World, ed John Shepherd and David Horn, 345-346. London: Lontinuum.

Mannone, Nathanael. 2012. "Musical Protest and Revolutionary Media. Capital Transformation among Artists, Activists, and Journalists during the 14 January Revolution." Master's thesis, The American University in Cairo, Cairo.

Meskini, Wael. 2011. Heartless places. Song. Downloaded Sound Cloud 21 February 2013, 4:o6. https://soundcloud.com/waelmeskini/wael-meskini-heartless-places (accessed 10 February 2017).

Nouveau Systeme. 2011. Live Art. Not recorded. http://www.youtube.com/watch?v =Ass_8KwP6Yo [viewed dd.mm.2016]

Onodera, Henri. 2015. Being a young activist in the late Mubarak era: An ethnography of political engagement in Egypt. Helsinki: University of Helsinki.

Palma, Agatha E. 2014. "Of Laws Tattooed in Flesh: Street Poetry, Hip-hop, and Graffiti and the Contest for Public Space in Post-Revolutionary Tunisia." Master's thesis, University of California Los Angeles, Los Angeles. Electronic Theses and Dissertations. http://escholarship.org/uc/item/58f9q4x2\#page-1 (accessed 13.10.2016).

Quiñones, Sandra.2015.Negotiating Entangled Contradictions about Being WellEducated: Nudos (Knots) in the Lives of Bilingual Latina Teachers. Duquesne University. https://www2.nau.edu/nabej-p/ojs/index.php/njrp/article/download/73/76 (accessed 13.10.2016).

Skalli, Loubna H. 2012. "Youth, Media and the Art of Protest in North Africa". In The Arab Uprisings, ed. Adel Iskander and Bassam Haddad, 124-130. Egypt: Tadween Press.

Street, John. 2012. Music and Politics. Cambridge \& Malden: Polity Press.

Toynbee, Jason. 2012. Music, Culture, and Creativity. In The Cultural Study of Music. A Critical Introduction. 2nd edition, ed. Martin Clayton, Trevor Herbert and Richard Middleton, 161-171. New York \& London: Routledge.

Westin, Lucia G. 2013. "Tunisian Music: The Soundtrack of the Revolution, the Voice of the People." In the journal The Phenomenon of Singing of the choral festival "Festival 500", edited by Ki Adams and Andrea Rose, 9: 229-237. http://journals.library.mun .ca/ojs/index.php/singing/article/view/1038 (accessed 9.1.2017).

Young, Iris Marion. 2000. Responsibility for Justice. Oxford: Oxford University Press. 